\title{
Halomonas shengliensis sp. nov., a moderately halophilic, denitrifying, crude-oil-utilizing bacterium
}

Correspondence
Xiao-Lei Wu
xiaolei_wu@tsinghua.edu.cn

\author{
Ya-Nan Wang, ${ }^{1}$ Hua Cai, ${ }^{1}$ Chang-Qiao Chi, ${ }^{1}$ An-Huai Lu, ${ }^{2}$ Xian-Gui Lin, ${ }^{3}$ \\ Zheng-Feng Jiang ${ }^{1}$ and $\mathrm{Xiao}^{-L e i} \mathrm{Wu}^{1}$
}

\author{
${ }^{1}$ Department of Environmental Science and Engineering, Tsinghua University, Beijing 100084, \\ China \\ ${ }^{2}$ Department of Geology, Peking University, Beijing 100871, China \\ ${ }^{3}$ Institute of Soil Science, Chinese Academy of Sciences, Nanjing 210008, China
}

The bacterial genus Halomonas contains numerous moderately halophilic species with different biochemical functions including: denitrification [Halomonas desiderata (Berendes et al., 1996), H. campisalis (Mormile et al., 1999)], production of exopolysaccharides [Halomonas eurihalina (Mellado et al., 1995), H. maura (Bouchotroch et al., 2001), H. ventosae (Martínez-Cánovas et al., 2004)] and degradation of aromatic compounds (Halomonas organivorans; García et al., 2004). Because of the diverse functions of these moderately halophilic bacteria, in recent years we have focused on the characterization of the moderately halophilic bacterial community that is able to degrade petroleum hydrocarbons in several saline oilfields of China. Bacterial strains that could use crude oil as the sole carbon source were isolated ( $\mathrm{Gu}$ et al., 2007; Wang et al., 2007), among which was strain SL014B-85 ${ }^{\mathrm{T}}$. Based on its phenotypic, physiological, biochemical and phylogenetic characteristics, strain SL014B- $85^{\mathrm{T}}$ is considered to represent a novel species of the genus Halomonas.

Strain SL014B-85 ${ }^{\mathrm{T}}$ was isolated from an oil-polluted saline soil from the coastal Shengli oilfield, in Shangdong Province in eastern China, by a 10-fold dilution plating technique on

The GenBank/EMBL/DDBJ accession number for the $16 \mathrm{~S}$ rRNA gene sequence of strain SL014B-85 ${ }^{\top}$ is EF121853. oil-produced water (OPW) agar plates (Wang et al., 2007) at $30{ }^{\circ} \mathrm{C}$. As the organic and mineral contents of the oilproducing water were constantly changing, cultivation of strain SL014B- $85^{\mathrm{T}}$ for identification purposes was carried out in artificial seawater (ASW) medium, consisting of $5 \mathrm{~g}$ peptone, $1 \mathrm{~g}$ yeast extract, $4 \mathrm{~g} \mathrm{Na}_{2} \mathrm{SO}_{4}, 0.68 \mathrm{~g} \mathrm{KCl}$, $0.1 \mathrm{~g} \mathrm{KBr}, \quad 0.025 \mathrm{~g}^{\mathrm{H}} \mathrm{H}_{3} \mathrm{BO}_{3}, \quad 5.4 \mathrm{~g} \quad \mathrm{MgCl}_{2} \cdot \mathrm{H}_{2} \mathrm{O}, \quad 1.5 \mathrm{~g}$ $\mathrm{CaCl}_{2} \cdot 2 \mathrm{H}_{2} \mathrm{O}, 0.024 \mathrm{~g} \mathrm{SrCl}_{2} \cdot 6 \mathrm{H}_{2} \mathrm{O}, 0.2 \mathrm{~g} \mathrm{NaHCO}_{3}, 0.04 \mathrm{~g}$ $\mathrm{Na}_{2} \mathrm{HPO}_{4}, 0.5 \mathrm{~g} \mathrm{NH}_{4} \mathrm{Cl}$ and $0.002 \mathrm{~g} \mathrm{NaF}$, per litre of water, with $2.4 \%(\mathrm{w} / \mathrm{v}) \mathrm{NaCl}(\mathrm{pH}$ 8.0) (Eguchi et al., 1996).

After growth in ASW medium for 2 days at $30^{\circ} \mathrm{C}$, cell morphology was examined via transmission electron microscopy. Salt requirement for growth was tested by using ASW medium with $\mathrm{NaCl}$ concentrations ranging from 0 to $30 \%$ $(\mathrm{w} / \mathrm{v})\left(\mathrm{pH} \mathrm{8.0,}\right.$ at $\left.30^{\circ} \mathrm{C}\right)$ (Bouchotroch et al., 2001). $\mathrm{pH}$ and temperature requirements for growth were determined in ASW medium by adjusting $\mathrm{pH}$ values between 2.0 and 12.0 $\left(30^{\circ} \mathrm{C}\right)$ and by incubation at $4-50{ }^{\circ} \mathrm{C}(\mathrm{pH} 8.0)$.

Oxidase activity was tested as described by Smibert \& Krieg (1994) and catalase activity was determined by use of a $3 \%$ (v/v) hydrogen peroxide solution. Nitrite and nitrate reduction were tested in ASW medium by growing the cells separately in the presence of nitrite and nitrate (Berendes et al., 1996). Denitrification was tested by growing the cells 
anaerobically in the presence of nitrate (Zumft, 1992). Hydrolysis of starch, gelatin and Tween 80 , urease activity, and growth on sole carbon sources were examined according to the procedures of Williams et al. (1983) on ASW medium without organic compounds at $30^{\circ} \mathrm{C}$ for 5-7 days. $\mathrm{H}_{2} \mathrm{~S}$ production was tested in ASW medium supplemented with $0.01 \%$ L-cysteine, the indicator being a strip of paper impregnated with lead acetate placed in the neck of the tube (Clarke, 1953; Mata et al., 2002).

Strain SL014B-85 ${ }^{\mathrm{T}}$, Halomonas alimentaria DSM $15356^{\mathrm{T}}$ and H. ventosae DSM $15911^{\mathrm{T}}$ were grown in ASW medium for 3 days at $30^{\circ} \mathrm{C}$; their cellular fatty acids were analysed as described by Komagata \& Suzuki (1987), and then tested by using GC/MS following the instructions of the Microbial Identification System (MIDI; Microbial ID Inc.). Polar lipid analyses were performed following a standard extraction procedure, and polar lipids were then tested by one- and two-dimensional TLC on Merck silica gel $60 \mathrm{~F}_{254}$ aluminium-backed thin-layer plates according to the methods of Kates (1986) and Collins et al. (1980). Isoprenoid quinones were analysed as described by Komagata \& Suzuki (1987), by using an HPLC fitted with a reversed-phase column (Shimpack, VP-ODS; Shimadzu).

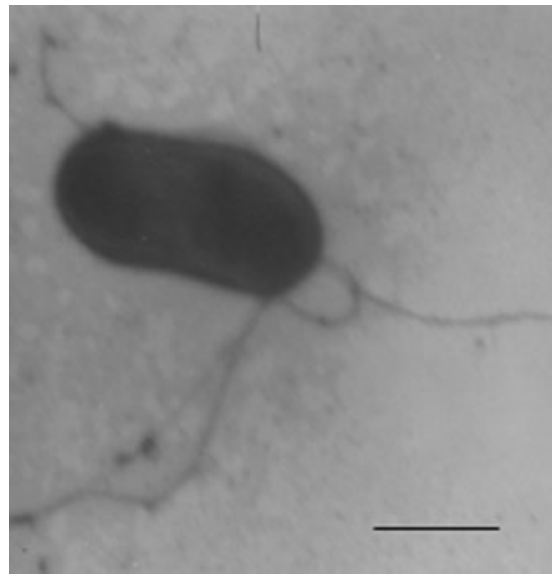

Fig. 1. Transmission electron micrograph of negatively stained cells of strain SL014B-85'. Bar, $0.5 \mu \mathrm{m}$.

Genomic DNA was extracted from cells grown in ASW medium for 2 days at $30^{\circ} \mathrm{C}$ according to the method of Marmur (1961). Purity was assessed based on $A_{280} / A_{260}$ and $A_{230} / A_{260}$ ratios (Johnson, 1994). The $\mathrm{G}+\mathrm{C}$ content of the

Table 1. Differential physiological and biochemical characteristics between strain SLO14B-85 ${ }^{\top}$ and closely related $H a l o m o n a s$ type strains

Data for H. alimentaria and H. ventosae are from Yoon et al. (2002) and Martínez-Cánovas et al. (2004). All are Gram-negative rods, positive for oxidase, catalase, aerobic and anaerobic nitrate reduction and negative for hydrolysis of gelatin, starch and Tween 80 and production of $\mathrm{H}_{2} \mathrm{~S}$. All can utilize glucose, sucrose, trehalose, DL-malate and succinate, but not ribose, arabinose, fructose, cellobiose, maltose, sorbose or xylose as sole carbon sources in ASW medium. +, Positive; -, negative; w, weak growth; ND, no data available.

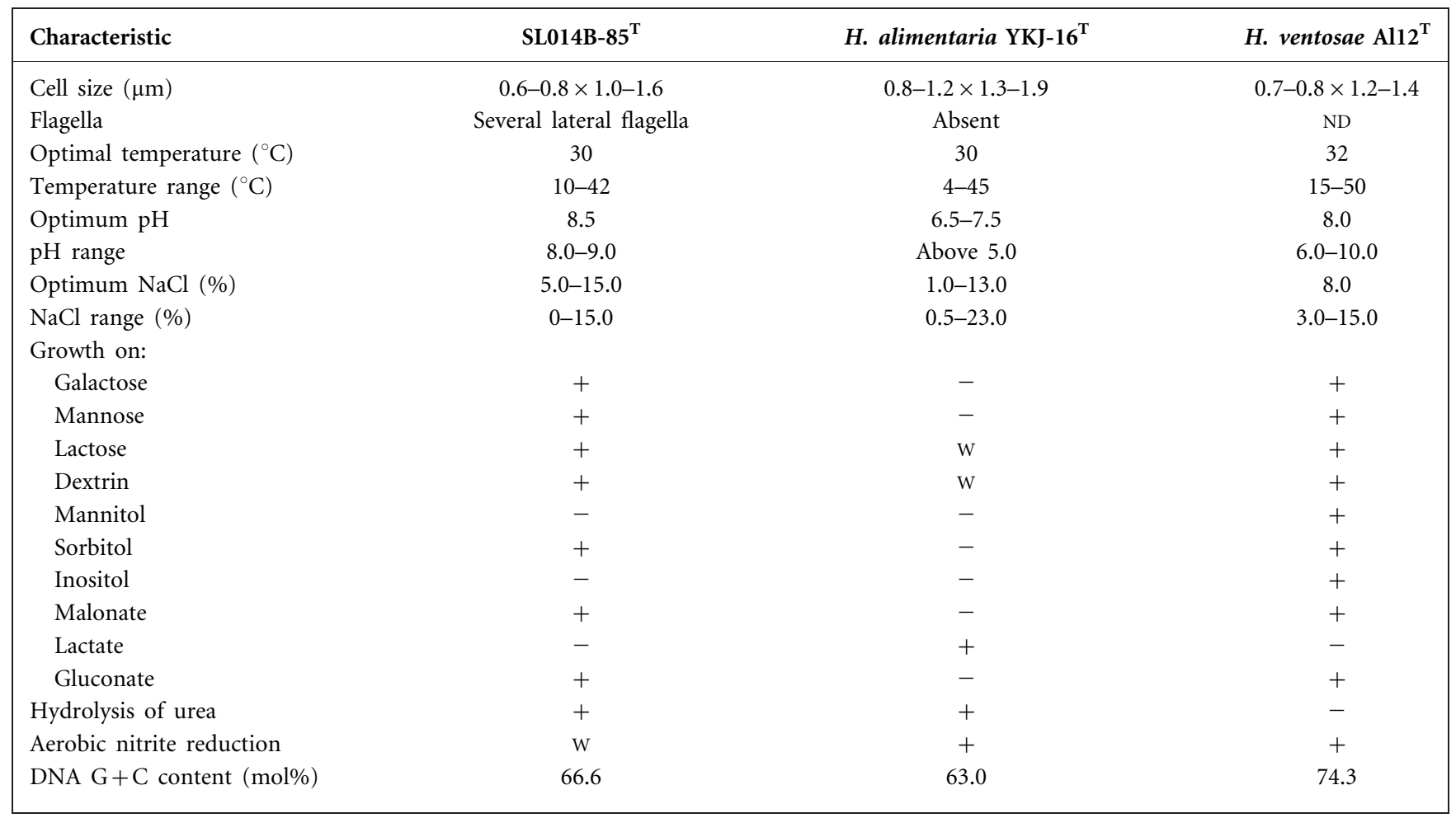


genomic DNA was determined by thermal denaturation (Marmur \& Doty, 1962) with DNA from Escherichia coli $\mathrm{K}-12$ as a control. DNA-DNA hybridization experiments were performed in triplicate following the methods of De Ley et al. (1970) and Huß et al. (1983). The 16S rRNA gene was amplified (Embley, 1991) with universal bacterial primers corresponding to E. coli positions 8F (5'-AGAGTTTGATCCTGGCTCAG) and 1492R (5'-GGTTACCTTGTTACGACTT). The 16S rRNA gene sequence of strain SL014B- $85^{\mathrm{T}}$ was aligned with those of related Halomonas species by using MEGA software (Kumar et al., 2004). Phylogenetic trees were constructed via the neighbour-joining method (Saitou \& Nei, 1987) and maximum-parsimony algorithm of MEGA, version 5.0 (Kumar et al., 2004), and reevaluated with the interior branch test of phylogeny.

Cells of strain SL014B- $85^{\mathrm{T}}$ were Gram-negative, short-rods $(0.6-0.8 \times 1.0-1.6 \mu \mathrm{m})$ with several lateral flagella (Fig. 1). Colonies on ASW agar plates were creamy and circular. Growth occurred at 0-15\% (w/v) $\mathrm{NaCl}$ (optimum 5-15\%), $\mathrm{pH}$ 8.0-9.0 (optimum $\mathrm{pH} 8.5$ ) and $10-42{ }^{\circ} \mathrm{C}$ (optimum $30{ }^{\circ} \mathrm{C}$ ). The strain was positive for oxidase, catalase and urease activities, aerobic nitrate and nitrite reduction, as well as for anaerobic nitrate reduction, but negative for hydrolysis of starch, gelatin and Tween 80 and $\mathrm{H}_{2} \mathrm{~S}$ production (Table 1). Strain SL014B- $85^{\mathrm{T}}$ was able to use glucose, sucrose, lactose, mannose, trehalose, galactose, dextrin, gluconate, malate, malonate, succinate and sorbitol, but not ribose, arabinose, fructose, cellobiose, maltose, sorbose, xylose, mannitol, inositol or lactate as sole carbon sources in ASW medium (Table 1). In addition, it was able to grow with the crude oil from Shengli oilfield as the sole carbon source.

The predominant cellular fatty acids of strain SL014B$85^{\mathrm{T}}$ were $\mathrm{C}_{18: 1} \omega 7 c\left(43.05 \%\right.$ of total fatty acids), $\mathrm{C}_{16: 0}$ (24.81\%), $\mathrm{C}_{19: 0}$ cyclo $\omega 8 c(10.14 \%), \mathrm{C}_{12: 0} 3-\mathrm{OH}(8.41 \%)$, $\mathrm{C}_{16: 1} \omega 7 c$ and/or iso- $\mathrm{C}_{15: 0} 2-\mathrm{OH}(6.98 \%), \mathrm{C}_{12: 0}(2.70 \%)$ and $\mathrm{C}_{10: 0}(1.73 \%)$ (Table 2), and ubiquinone with nine isoprene units (Q9) was the only isoprenoid quinone. The predominant polar lipids of strain SL014B- $85^{\mathrm{T}}$ were phosphatidylglycerol, diphosphatidylglycerol and phosphatidylethanolamine, which are characteristic of members of the genus Halomonas. The $\mathrm{G}+\mathrm{C}$ content of the DNA of strain SL014B- $85^{\mathrm{T}}$ was $66.6 \mathrm{~mol} \%$, within the range of 52$68 \mathrm{~mol} \%$ reported for the genus Halomonas by Franzmann \& Tindall (1990), but distinct from the most closely related species H. alimentaria (63.0 mol\%; Yoon et al., 2002) and $H$. ventosae (74.3 mol\%; Martínez-Cánovas et al., 2004).

The nearly complete $16 \mathrm{~S}$ rRNA gene sequence (1460 bp) was determined for strain SL014B- $85^{\mathrm{T}}$. Phylogeny of the $16 \mathrm{~S}$ rRNA gene sequences revealed that strain SL014B- $85^{\mathrm{T}}$ was a member of the Gammaproteobacteria and had a close phylogenetic relationship with species of the genus Halomonas, forming a cluster with $H$. alimentaria DSM $15356^{\mathrm{T}}$, H. ventosae DSM $15911^{\mathrm{T}}$, Halomonas cupida DSM $4740^{\mathrm{T}}$ (Baumann et al., 1983; Dobson \& Franzmann, 1996) and Halomonas halodenitrificans DSM $735^{\mathrm{T}}$ (Dobson \&
Table 2. Fatty acid profiles of strain SL014B- $85^{\top}$ and closely related type strains

Cells of all three strains were grown in ASW medium at $30{ }^{\circ} \mathrm{C}$ for 2 days before harvest. Values are percentages of total fatty acids. Data for $H$. alimentaria $\mathrm{YKJ}-16^{\mathrm{T}}$ were taken from Yoon et al. (2002).

\begin{tabular}{|lccc|}
\hline Fatty acid & $\begin{array}{c}\text { SL014B- } \\
\mathbf{8 5}^{\mathbf{T}}\end{array}$ & $\begin{array}{c}\text { H. alimentaria } \\
\text { YKJ-16 }^{\mathbf{T}}\end{array}$ & $\begin{array}{c}\text { H. ventosae } \\
\text { DSM 15911 }\end{array}$ \\
\hline $\mathrm{C}_{10: 0}$ & 1.73 & 1.9 & 2.20 \\
Unknown ECL 11.799 & 0.57 & - & - \\
$\mathrm{C}_{12: 0}$ & 2.70 & - & 6.79 \\
$\mathrm{C}_{12: 0}$ 3-OH & 8.41 & 5.2 & - \\
$\mathrm{C}_{14: 0}$ & - & 1.2 & - \\
Summed feature $3^{*}$ & 6.98 & 24.2 & 16.44 \\
$\mathrm{C}_{16: 0}$ & 24.81 & 27.0 & 27.26 \\
$\mathrm{C}_{17: 0}$ cyclo & 0.48 & 5.1 & 1.35 \\
$\mathrm{C}_{17: 0}$ & 0.54 & 0.2 & - \\
$\mathrm{C}_{18: 0}$ & 0.57 & 0.2 & 0.69 \\
$\mathrm{C}_{18: 1} \omega 7 c$ & 43.05 & 19.4 & 30.23 \\
$11-$ Methyl C $18: 1 \omega 7 c$ & - & 0.4 & 0.71 \\
Unknown ECL $18.846_{\mathrm{C}_{19: 0} \text { cyclo } \omega 8 c}^{-}$ & 10.14 & 12.9 & - \\
$\mathrm{C}_{20: 2} \omega 6,9 c$ & - & 0.2 & - \\
\hline
\end{tabular}

${ }^{*}$ Summed features represent groups of two or three fatty acids that could not be separated by GLC with the MIDI system. Summed feature 3 comprised $\mathrm{C}_{16: 1} \omega 7 c$ and/or iso- $\mathrm{C}_{15: 0} 2-\mathrm{OH}$.

Franzmann, 1996) (Fig. 2). Strain SL014B- $85^{\mathrm{T}}$ showed $16 \mathrm{~S}$ rRNA gene sequence similarity of 98.1 and $97.8 \%$, respectively, to the type strains of the most closely related species $H$. alimentaria and $H$. ventosae. DNA-DNA hybridization experiments were carried out in triplicate and results showed mean levels of relatedness of $30.5 \pm 0.06 \%$ to $H$. alimentaria DSM $15356^{\mathrm{T}}$ and $15.5 \pm 0.07 \%$ to $H$. ventosae DSM $15911^{\mathrm{T}}$, indicating that strain SL014B-85 ${ }^{\mathrm{T}}$ was genotypically distinct from these type strains (Wayne et al., 1987).

Based on the above data and the full description provided below, we propose that strain SL014B- $85^{\mathrm{T}}$ represents a novel species of the genus Halomonas, for which the name Halomonas shengliensis sp. nov. is proposed.

\section{Description of Halomonas shengliensis sp. nov.}

Halomonas shengliensis (sheng.li.en'sis. N.L. fem. adj. shengliensis pertaining to Shengli oilfield, China, where the type strain was isolated).

Cells are moderately halophilic, Gram-negative, crude-oilutilizing short rods $(0.6-0.8 \times 1.0-1.6 \mu \mathrm{m})$ with several lateral flagella. Colonies on ASW agar are creamy and circular. Grows at $0-15 \%(\mathrm{w} / \mathrm{v}) \mathrm{NaCl}, \mathrm{pH} 8.0-9.0$ and $10-42{ }^{\circ} \mathrm{C}$; optimum growth occurs at $5-15 \%(\mathrm{w} / \mathrm{v}) \mathrm{NaCl}$, pH 8.5 and $30^{\circ} \mathrm{C}$. Utilizes glucose, sucrose, lactose, 


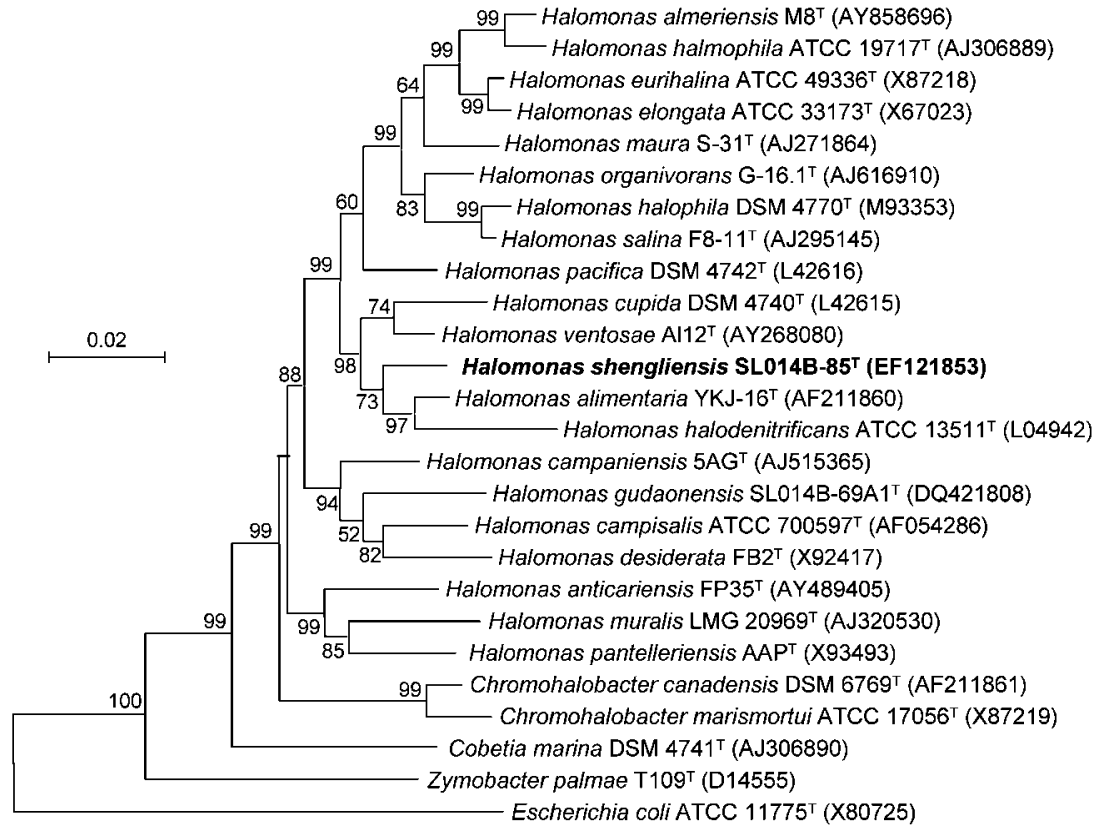

Fig. 2. Neighbour-joining phylogenetic tree based on 16S rRNA gene sequences showing the relationship between strain SL014B$85^{\mathrm{T}}$ and members of the genus Halomonas and related genera within the family Halomonadaceae. Bootstrap values (\%) are based on 1000 replicates and are shown for branches with more than $50 \%$ support Bar, 0.02 expected changes per site. mannose, galactose, dextrin, gluconate, malate, malonate, succinate and sorbitol as sole carbon sources. Oxidase-, urease- and catalase-positive, but negative for hydrolysis of starch, Tween 80 and gelatin and production of $\mathrm{H}_{2} \mathrm{~S}$. It is able to reduce nitrate anaerobically as well as nitrate and nitrite aerobically. Q9 is the only isoprenoid quinone and phosphatidylglycerol, diphosphatidylglycerol and phosphatidylethanolamine are the predominant polar lipids. The main cellular fatty acids are $\mathrm{C}_{18: 1} \omega 7 c(43.05 \%), \mathrm{C}_{16: 0}$ $(24.81 \%)$ and $\mathrm{C}_{19: 0}$ cyclo $\omega 8 c(10.14 \%)$. The DNA G + C content of the type strain is $66.6 \mathrm{~mol} \%$.

The type strain, SL014B-85 ${ }^{\mathrm{T}}$ (=CGMCC $1.6444^{\mathrm{T}}=\mathrm{LMG}$ $23897^{\mathrm{T}}$ ), was isolated from a saline soil from the coastal Shengli oilfield in eastern China.

\section{Acknowledgements}

We would like to thank G.-F. Zhao, S.-L. Yu and Y.-F. Guo for their valuable help. This study was supported by the National Natural Science Foundation of China $(30570033,30300008)$ and the National Basic Research Program of China (2005CB221308).

\section{References}

Baumann, L., Bowditch, R. D. \& Baumann, P. (1983). Description of Deleya gen. nov. created to accommodate the marine species Alcaligenes aestus, A. pacificus, A. cupidus, A venustus, and Pseudomonas marina. Int J Syst Bacteriol 33, 793-802.

Berendes, F., Gottschalk, G., Heine-Dobbernack, E., Moore, E. R. B. \& Tindall, B. J. (1996). Halomonas desiderata sp. nov., a new alkaliphilic, halotolerant and denitrifying bacterium isolated from a municipal sewage works. Syst Appl Microbiol 19, 158-167.
Bouchotroch, S., Quesada, E., Del Moral, A., Liamas, I. \& Béjar, V. (2001). Halomonas maura sp. nov., a novel moderately halophilic, exopolysaccharide-producing bacterium. Int J Syst Evol Microbiol 51, $1625-1632$.

Clarke, P. H. (1953). Hydrogen sulphide production by bacteria. J Gen Microbiol 8, 397-407.

Collins, M. D., Goodfellow, M. \& Minnikin, D. E. (1980). Fatty acid isoprenoid quinine and polar lipid composition in the classification of Curtobacterium and related taxa. J Gen Microbiol 118, 29-37.

De Ley, J., Cattoir, H. \& Reynaerts, A. (1970). The quantitative measurement of DNA hybridization from renaturation rates. Eur J Biochem 12, 133-142.

Dobson, S. J. \& Franzmann, P. D. (1996). Unification of the genera Deleya (Baumann et al. 1983), Halomonas (Vreeland et al. 1980) and Halovibrio (Fendrich 1988) and the species Paracoccus halodenitrificans (Robinson and Gibbons 1952) into a single genus, Halomonas, and placement of the genus Zymobacter in the family Halomonadaceae. Int J Syst Bacteriol 46, 550-558.

Eguchi, M., Nishikawa, T. \& Macdonald, K. (1996). Responses to stress and nutrient availability by the marine ultramicrobacterium Sphingomonas sp. strain RB2256. Appl Environ Microbiol 62, 1287-1294.

Embley, T. M. (1991). The linear PCR reaction: a simple and robust method for sequencing amplified rRNA genes. Lett Appl Microbiol 13, 171-174.

Franzmann, P. D. \& Tindall, B. J. (1990). A chemotaxonomic study of members of the family Halomonadaceae. Syst Appl Microbiol 13, 142-147.

García, M. T., Mellado, E., Ostos, J. C. \& Ventosa, A. (2004). Halomonas organivorans sp. nov., a moderate halophile able to degrade aromatic compounds. Int J Syst Evol Microbiol 54, 1723-1728.

Gu, J., Cai, H., Yu, S.-L., Qu, R., Yin, B., Guo, Y.-F., Zhao, J.-Y. \& Wu, X.-L. (2007). Marinobacter gudaonensis sp. nov., isolated from an oilpolluted saline soil in a Chinese oilfield. Int J Syst Evol Microbiol 57, 250-254. 
Huß, V. A. R., Festl, H. \& Schleifer, K. H. (1983). Studies on the spectrometric determination of DNA hybridization from renaturation rates. Syst Appl Microbiol 4, 184-192.

Johnson, J. L. (1994). Similarity analysis of DNAs. In Methods for General and Molecular Bacteriology, pp. 655-681. Edited by P. Gerhardt, R. G. E. Murray, W. A. Wood \& N. R. Krieg. Washington, DC: American Society for Microbiology.

Kates, M. (1986). Techniques of Lipidology, 2nd edn. Amsterdam: Elsevier.

Komagata, K. \& Suzuki, K. (1987). Lipid and cell wall analysis in bacterial systematics. Methods Microbiol 19, 161-206.

Kumar, S., Tamura, K. \& Nei, M. (2004). MEGA3: integrated software for molecular evolutionary genetics analysis and sequence alignment. Brief Bioinform 5, 150-163.

Marmur, J. (1961). A procedure for the isolation of deoxyribonucleic acid from microorganisms. J Mol Biol 3, 208-218.

Marmur, J. \& Doty, P. (1962). Determination of the base composition of deoxyribonucleic acid from its thermal denaturation temperature. J Mol Biol 5, 109-118.

Martínez-Cánovas, M. J., Quesada, E., Llamas, I. \& Béjar, V. (2004). Halomonas ventosae sp. nov., a moderately halophilic, denitrifying, exopolysaccharide-producing bacterium. Int J Syst Evol Microbiol 54, 733-737.

Mata, J. A., Martinez-Cánovas, J., Quesada, E. \& Béjar, V. (2002). A detailed phenotypic characterisation of the type strains of Halomonas species. Syst Appl Microbiol 25, 360-375.

Mellado, E., Moore, E. R. B., Nieto, J. J. \& Ventosa, A. (1995). Phylogenetic inferences and taxonomic consequences of $16 \mathrm{~S}$ ribosomal DNA sequence comparison of Chromohalobacter marismortui, Volcaniella eurihalina, and Deleya salina and reclassification of $V$. eurihalina as Halomonas eurihalina comb. nov. Int J Syst Bacteriol 45, 712-716.
Mormile, M. R., Romine, M. F., Garcia, M. T., Ventosa, A., Bailey, T. J. \& Peyton, B. M. (1999). Halomonas campisalis sp. nov., a denitrifying, moderately haloalkaliphilic bacterium. Syst Appl Microbiol 22, 551-558.

Saitou, N. \& Nei, M. (1987). The neighbor-joining method: a new method for reconstructing phylogenetic trees. Mol Biol Evol 4, 406-425.

Smibert, R. M. \& Krieg, N. R. (1994). Phenotypic characterization. In Methods for General and Molecular Bacteriology, pp. 607-654. Edited by P. Gerhardt, R. G. E. Murray, W. A. Wood \& N. R. Krieg. Washington, DC: American Society for Microbiology.

Wang, Y.-N., Cai, H., Yu, S.-L., Wang, Z.-Y., Liu, J. \& Wu, X.-L. (2007) Halomonas gudaonensis sp. nov., isolated from a saline soil contaminated by crude oil. Int J Syst Evol Microbiol 57, 911-915.

Wayne, L. G., Brenner, D. J., Colwell, R. R., Grimont, P. A. D., Kandler, O., Krichevsky, M. I., Moore, L. H., Moore, W. E. C., Murray, R. G. E. \& other authors (1987). International Committee on Systematic Bacteriology. Report of the ad hoc committee on reconciliation of approaches to bacterial systematics. Int J Syst Bacteriol 37, 463-464.

Williams, S. T., Goodfellow, M., Alderson, G., Wellington, E. M. H., Sneath, P. H. A. \& Sackin, M. J. (1983). Numerical classification of Streptomyces and related genera. J Gen Microbiol 129, 1743-1813.

Yoon, J.-H., Lee, K.-C., Kho, Y. H., Kang, K. H., Kim, C.-J. \& Park, Y.-H. (2002). Halomonas alimentaria sp. nov., isolated from jeotgal, a traditional Korean fermented seafood. Int J Syst Evol Microbiol 52, 123-130.

Zumft, W. G. (1992). The denitrifying bacteria. In The Prokaryotes. A Handbook on the Biology of Bacteria: Ecophysiology, Isolation, Identification, Applications, 2nd edn, pp. 554-582. Edited by A. Balows, H. G. Trüper, M. Dworkin, W. Harder \& K. H. Schleifer. New York: Springer. 